\title{
STUDI KOMPARATIF TAKAFUL DAN ASURANSI KONVENSIONAL
}

\author{
Eja Armaz Hardi \\ email:eja.armaz.hardi@gmail.com
}

\begin{abstract}
The development of the sect of the sect of the conventional economic science gave birth to two large flows in the economic system of the countries in the world. The First, the classic economic ideologies known with monetary policy in order to maintain the stability of the state keekonomian. The second, understands the modern economy that focusing the policy of the government in the fiscal sector. In the middle of the rivalry between two economic ideologies, on the decade of the 1970s in gagaslah an economic system which is considered as the solution to accommodate the problems faced by a negra. The Islamic economy with the basic philosophy that tend to be outside of the mainstream economy offers the principle of values and the purpose of the comprehensive and universal.

In the economic system countries there financial institutions

Banks and non-bank. In the adjacent is the author membahasakan one of non-bank financial institutions, namely insurance. As in conventional financial institutions there are insurance, so also on the sharia financial institutions have sharia insurance named with takaful. The subject of done author is gives a comparison between the conventional insurance and takaful. So that can provide a description of the opportunities takaful development in Indonesia as a whole.

The Annual Report Bappepam-LK 2011 syariah insurance

(takaful) number of wealth and investment funds owned by Rp9,2

Trillion and Rp7,8 Triliundan growth that occurs on this industry of $31,94 \%$ and $33,76 \%$. From this study by relying on the principle that is owned by the takaful conclusion can be that takaful in Indonesia still have opportunities that is large enough to perform the expansion of the market by touching the middle to society.
\end{abstract}

Key Words: Insurance, Shari`a, Takaful, Islamic Economy 
Studi Komparatif Takaful dan Asuransi Konvensional

\section{PENDAHULUAN}

\section{A. La tar Belakang}

Sistem ekonomi terus mengalami perkembangan pada seluruh aspek beriring dengan perkembangan teknologi, rasionalitas dan tataran sosial kehidupan manusia. Perkembangan sistem ini di tunjukkan oleh sistem ekonomi barat atau yang sering dikenal dengan sistem ekonomi konvensional, hal ini ditunjukan melalui lahirnya beberapa paham ekonomi. Awal mula dari sistem ekonomi konvensional adalah dengan munculnya buku "An Incuiry into the nature and causes of the wealth of nation" oleh Adam Smith pada tahun 1776-an yang merupakan guru besar dari Glasgow, ini merupakan cikal bakal yang kemudian disebut sebagai mazhab klasik atau mazhab liberal (Kaslan, 1975 : 25). Lebih kurang 160 tahun kemudian atau satu setengah abad lebih mazhab ini dirasa tidak lagi dapat mengakomodir berbagai permasahan negara penganutnya. Berangkat dari kegelisahan itu, pada tahun 1936-an muncul kembali pandangan baru dalam sistem ekonomi yang dikenal dengan ekonomi modern yang diusung oleh JM Keynes. Hingga kini kedua paham tersebut terus berkembang dan saling mengambil peran dalam perekonomian dunia. Dengan demikian konsep trial and error dalam ilmu ekonomi menunjukkan kepada kita bahwa perkembangan suatu ilmu pengetahuan dalam rangka mencapai kemapanan sebuah sistem mumbutuhkan waktu yang tidak singkat. Ditengah gejolak dua mazhad ekonomi di atas, dianggap sebagai suatu sistem

perekonomian yang dapat memberikan solusi dari kegagalan sistem sebelumnya. Pada kisaran tahun 1970-an diadakanlah pertemuan para ahli ekonomi dari berbagai negara-negara muslim di Jeddah-Arab Saudi. Pertemuan tersebut merumuskan bagaimana ekonomi Islam kedepan. Walaupun ekonomi Islam sudah dikenal sejak zaman Rosulullah SAW., pelabelan sistem ekonomi dengan nama "Islam" atau "Syariah" baru muncul secara massif pada pertengahan abad ke-19. Beberapa bukti yang menunjukan bahwa eksistensi sistem ekonomi Islam telah berjalan sejak zaman RosulullahSAW., adalah apa yang telah dipraktikkan 
oleh pribadi Rosulullah dalam menjalankan aktivitas ekonomi. Dalam menjalankan aktivitas ekonomi tersebut menandakan bahwa sistem ekonomi yang berbasiskan Al-quran dan Sunnah telah benar-benar ada sejak awal munculnya Islam.

Sistem ekonomi Islam memiliki karakeristik yang sangat berbeda dengan sistem ekonomi konvensional. Dimana ekonomi Islam mengedepankan keberkahan dari setiap transaksi keekonomian, ada hubungan transedental dalam kegiatan ekonomi dan lainnya. Perbedaan substansial inilah yang diklaim bahwa sistem ekonomi Islam diharapkan suatu saat akan men-substitusi sistem ekonomi saat ini. Salah satu instrument dalam perekonommian adalah lembaga keuangan. Lembaga keuangan baik konvensional maupun syariah dibagi menjadi dua sektor lembaga kuangan yaitu: lembaga keuangan bank dan lembaga keuangan non-bank. Salah satu dari banyak lembaga keuangan non-bank pada sektor syariah adalah asuransi yang disebut juga dengan takaful, model akad yang digunakan bisa dengan bentuk tijarah dan bisa juga dengan bentuk tabarru (Haykal, 2010 : 181). Asuransi dengan segala perdebatannya masih memiliki sisi positif dalam memberikan manfaat dan mentranfer nilai-nilai Islam melalui transaksi ekonomi. Kompleksitas produk, kontrak yang terdapat pada lembanga keuangan syariah bank atau non-bank serta minimnya pengetahuan masyarakat terhadap substansi produk dan kontrak tersebut menjadikan perkembangan lembaga keuangan syariah bank atau non-bank cenderung lambat.

Menurut laporan tahunan Bappepam-LK menyebutkan bahwa pertumbuhan industri asuransi syariah cukup baik pada tahun 2011. Pertumbuhan industri ini ditunjukan oleh meningkatnya jumlah kekayaan dan dana invenstasi yang dimiliki industri perasuransian syariah sebesar Rp9,2 Triliun dan Rp7,8 Triliun (dilihat dari data yang belum dilakukan audit). Dari angka tersebut, pertumbuhan yang terjadi pada industri ini sebesar 31,94\% dan 33,76\%. Adapun dana bruto yang diperoleh dari iuran tabarru, ujrah yang diterima perusahaan dan jumlah kontribusi investasi pada tahun 2011 mencapai Rp4,7 Triliun atau mengalami kenaikan sebesar 
$34,89 \%$ dari tahun sebelumnya. Perdebatan yang belum mencapai titik temu diiringi dengan pertumbuhannya sebagai lembaga kuangan syariah non-bank menunjukkan asuransi syariah dilirik oleh masyarakat muslim di Indonesia. Namun permasalahan yang ingin diangkat oleh penulis mengenai asuransi adalah terkait dengan prinsip, tujuan dan fungsi asuransi syariah sebagai agent syariah yang memiliki peran s angat s akral d alam membantu masyarakat pada umumnya dan masyarakat muslim khususnya untuk merasakan nilai tambah (added value) dari adanya asuransi syariah (takaful).

\section{POKOK BAHASAN}

\section{A. Asuransi Konvensional}

Asuransi berasal dari bahasa belanda, assurantie yang didalam hukum belanda disebut dengan verzakering yang berarti pertanggungan. Dari definisi tersebut muncul beberapa istilah seperti assuaduer bagi penanggung dan geassureede bagi tertanggung (Syakir, 2004:26). Menurut laporan tahunan y ang d ikeluarkan oleh Bappepam-LK asuransi d ibagi menjadi dua bagian besar yaitu asuransi jiwa dan asuransi umum. Definisi Asuransi menurut Undang-Undang Republik Indonesia Nomor 2 Tahun 1992 tentang usaha perasuransian Bab 1, Pasal 1: "Asuransi atau Pertanggungan adalah perjanjian antara dua pihak atau lebih, dengan mana pihak penanggung mengikatkan diri kepada tertanggung dengan menerima premi asuransi, untuk memberikan penggantian kepada tertanggung karena kerugian, kerusakan atau kehilangan keuntungan yang diharapkan, atau tanggung jawab hukum kepada pihak ketiga yang mungkin akan diderita tertanggung, yang timbul dari suatu peristiwa yang tidak pasti, atau untuk memberikan suatu pembayaran yang didasarkan atas meninggal atau hidupnya seseorang yang dipertanggungkan".

Selain asuransi dengan pengertian yang dijelaskan oleh UURI tahun1992diatas, berbagai definisi asuransi yang substansinya adalah kontrak beberapa peserta selaku tertanggung kepada perusahaan asuransi sebagai penanggung yang berkeinginan untuk beri ganti rugi ketika mengalami suatu musibah, dengan terjadinya pertanggungan oleh perusahaan asuransi kepada tertanggung, maka tertanggung diwajibkan untuk membebayar 
premi berupa uang kepada perusahaan asuransi.

Akumulasi dana $\mathrm{d}$ ari pihak ketiga yang menjadi peserta asuransi y ang mengasuransikan suatu objek kepada perusahaan digunakan untuk selain membayarkan klaim kepada pereserta yang terkena musibah, dana tersebut juga dijadikan modal investasi oleh perusahaan disektor produktif. Yang mana hasil dari investasi tersebut akan kembali kepada perusahaan setelah dikurangi seluruh biaya operasiona perusahaan.

Dalam asuransi k onvensional s elama ini d ikenal d engan konsep pemindahan resiko (transfer of risk) dari peserta kepada peserta lain. Resiko dalam asuransi. konvensional di bagi menjadi tiga yaitu resiko murni, spekulatif dan induvidu. Dengan kata lain bahwa besaran premi yang harus dibayar oleh seorang pemegang asuransi di lihat dari besar kecilnya resiko yang di tanggung oleh perusahaan (Kasmir, $2014: 264$ ) Hal ini tidak dikenal pada asuransi syariah yang berkembang saat ini. Selajutnya asuransi konvensional diperbolehkan melakukan investasi dari dana perseta pada sektor apapun, baik sektor halal ataupun haram. Juga banyak akademisi ekonomi syariah meng-klaim bahwa kontrak asuransi konvensional banyak mengandung hal-hal yang dilarang dalam syariah Islam seperti masih adanya gharar, maisir, riba. Terjadinya gharar dalam asuransi konvensional adalah peserta tertanggung tidak mengetahui kapan ia akan tertimpa musibah dimasa yang akan datang, yang mana otoritas ini hanya terdapat pada Allah SWT. Ketidak jelasan inilah yang dijual oleh perusahaan asuransi kepada peserta tertanggung.

Sedangkan maisir pada perasuransian konvensional adalah memperoleh sesuatu dengan sangat mudah tanpa kerja keras atau mendapat keuntungan tanpa bekerja. Maisir sering diartikan dengan berjudi. Dalam industri asuransi konvensional, maisir dapat terjadi dalam tiga hal, yaitu: pertama, Ketika seorang pemegang polis mendadak terkena musibah sehingga memperoleh hasil klaim, padahal baru sebentar menjadi klien asuransi dan baru sedikit membayar premi. Jika ini terjadi, nasabah diuntungkan. Kedua, Sebaliknya, jika hingga akhir masa perjanjian tidak terjadi sesuatu, sementara ia sudah membayar premi secara penuh/lunas, maka perusahaanlah yang diuntungkan. Ketiga, apabila pemegang polis dengan sebab- 
sebab tertentu membatalkan kontraknya sebelum masa reversing period, maka yang bersangkutan tidak akan menerima kembali uang yang telah dibayarkan atau uangnya dianggap hangus.

Sedangkan pada aspek riba, Menurut Syeikh Yusuf AlQardhawi asuransi konvensional itu sama dengan judi, karena tertanggung mengharapkan harta jaminan atau tanggungan melebihi jumlah pembayaran preminya. Oleh sebab itu, dalam asuransi tersebut juga ada unsur ribanya (Syakir, 2004 : 299). Beberapa perusahaan asuransi diindonesia telah melakukan kerja sama kepada berbagai instansi y ang berhubungan langsung dengan masyarakat. Seperti ketika pembuatan Kartu Tanda Penduduk (KTP), Surat Izin M e ngemudi (SIM), tiket transpostasi darat, laut maupun udara, tanpa disadari bahwa mayarakat telah mendapatkan asuransi bila terjadi suatu yang sesuai dengan kriteria masing-masing kontrak ketika terjadinya musibah. Pengakaran sistem asuransi konvensional pada grass root ini belum terjadi pada asuransi syariah yang memiliki konsep yang sangat berbeda dengan konsep asuransi konvensional. Namun kelemahan yang terdapat pada asuransi konvensional yang telah mengakar pada setiap lini masyarakat tidak adanya laporan kepada peserta secara massif asuransi secara rinci mengenai dana yang telah dihasilkan oleh perusahaan atas investasi dana peserta. Selanjutnya perusahaan asuransi juga tidak dapat merangkul seluruh kejadian musibah yang terjadi pada masyarakat, sehingga mengakibatkan banyak musibah dimasyarakat yang seharusnya ditanggung oleh perusahaan asuransi menjadi tidak ditanggung oleh perusahaan asuransi. Hal ini memiliki beberapa kemungkinan akibat tidak adanya klaim yang diajkukan kepada pihak perusahaan asuransi. Dugaannya adalah ketidaktahuan masyarakat grass root bahwa ktp, sim yang dimiliki sudah diasuransikan pada perusahaan asuransi tertentu yang akan menanggung resiko yang akan terjadi. Juga kompleksitas prosedur yang diterapkan oleh peruahaan asuransi bagi masyarakat untuk mendapatkan klaim dari apa yang menimpanya.

Adapun prinsip asuransi konvensional menurut Joko Tri Haryanto baik asuransi umum atau asuransi jiwa adalah sebagai berikut: pertama, kepentingan yang dipertanggungkan (Insurable Interest). Kedua, kejujuran sempurna (Utmost Good Faith). Ketiga, 
Indemnitas (Indemnity). Ketiga, subrogasi (Subrogation). Keempat, Kontribusi (Contribution). Kelima, kausa proksimal (Proximate Cause).

\section{B. Asuransi Syariah (Takaful)}

Asuransi dalam bahasa arab dikenal dengan istilah takaful, ta'min atau tadamun. ta'min berarti memberikan rasa aman kepada salah satu pihak yang bertransaksi. Rasa aman dan terhindak dari was-was inilah yang menjadi objek transaksi $t a^{\prime}$ min yang dimaksud dalam istilah tersebut.

Pengertian asuransi syariah menurut fatwa DSN-MUI, yang lebih dikenal dengan ta'min, takaful, atau tadhamun adalah usaha saling melindungi dan tolong-menolong di antara sejumlah orang atau pihak melalui investasi dalam bentuk aset $d$ an atau tabarru memberikan pola pengembalian untuk menghadapi risiko tertentu melalui akad yang sesuai dengan syariah (Fatwa Dewan Syariah N asional. N o. 21/ DSN-MUI/X/2001).

Dari definisi yang dijelaskan oleh Fatwa DSN-MUI diatas menyatakan bahwa asuransi syarriah memiliki perbedaan substansial dengan asuransi konvensional. Pertama, kontrak awal pada asuransi syariah dimaksudkan diawal kontrak bahwa para peserta memiliki tujuan saling tolong menolong (tabaru) sesama peserta asuransi dengan cara menyisihkan sebagian dana mereka untuk saling membantu. Hal ini berbeda dengan kontrak yang terjadi pada asuransi konvensional, dimana terjadi pengelihan resiko (transfer of risk) kepada perusahaan asuransi dengan diwajibkan untuk membayar premi.

Sedangkan pada kontrak asuransi syariah, konsep yang digunakan adalah membagi resiko (share of risk) sesam peserta. Kadua, asuransi syariah dilandaskan dengan kontrak yang diperbolehkan oleh syariah. Sehingga asuransi syariah akan cendrung terhindar dari praktik yang dilarang oleh syariah seperti riba, gharar dan maisir sebagai mana yang terjadi pada kontrak asuransi konvensional. Begitu juga dengan aspek penyaluran dana selain dana tabaru peserta dalam investai produktif, asuransi syaraiah hanya diperbolehkan untuk melakukan investasi dengan batasan 
yang telah ditetapkan oleh syariah. Sedangkan asuransi konvensional diperbolehkan melakukan investasi dengan dana peserta pada sektor apapun.

\section{Prinsip Asuransi Syariah (Takaful)}

Asuransi syariah dibangun yang pertama adalah prinsip tauhid kepada Allah SWT. Begitu juga landasan berdirinya asurani syariah saling tolong menolong antar anggota, sehingga sebagaian dana peserta akan disisikan oleh perusahaan asuransi untuk digunakan sebagai dana tabaru yang digunakan untuk membantu sesama anggota asuransi apabila mengalami musibah atau objek yang menjadi kesepakatan sesama peserta. Dana tabaru ini dikategorikan pada dana shodakoh peserta yang tidak dapat diambil kembali oleh peserta, kecuali sebagian dana yang dimasukkan pada dana investasi bersama dalam sektor produktif yang sesuai dengan syariah. Dari prinsip tabarru yang diusungkan asuransi syariah juga menganut prinsip keadilan perlakuan sesama peserta dan kepada pihak pengelola yang dipercayaan untuk mengurus d ana peserta. Begitu juga prinsip amanah menjadi landasan bagi asuransi syariah dalam melakukan kegiatan dalam hal pengelolaan dana yang terkumpul dari para peserta.

\section{Tujuan Asuransi Syariah (Takaful)}

Asuransi syariah memiliki tujuan yang lebih komplek dibanding dengan asuransi konvensional. Asuransi syariah tidak hanya dituntut untuk mengejar profit yang dari investasi yang dilakukan dengan sebagian dana peserta. Namun lebih dari profit gain asuransi syariah juga memiliki tanggung jawab sosial dalam memberikan sosial edukasi kepada masyarakat tentang pentingnya tolong menolong sesama muslim dalam rangka menegakkan ajaran Islam ditengah- tengah masyarakat.

Tujuan asuransi syariah menurut Yadi Jawari, 2005 adalah: (Jawari, $2005: 13$ ) Menjaga konsistensi pelaksanaan syariah di bidang keuangan, antisipasi terhadap makin meningkatnya kemakmuran bangsa, turut meningkatkan kesadaran berasuransi masyarakat, dan menumbuhkan kemampuan umat Islam di bidang pengelolaan industri asuransi. Selain itu, tujuan berdirinya asuransi syariah adalah: Pertama, tolong-menolong 
dan bekerja sama, kekayaan yang dimiliki sebagai karunia Allah SWT hendaknya berfungsi sosial, terutama membebaskan orang dari penderitaan dan ketergantungan. Saling tolong dan bekerja sama merupakan salah satu sifat terpuji dan sangat dianjurkan oleh-Nya. Kedua, Saling menjaga keselamatan dan keamanan, kehendak untuk selamat dan aman dalam hidup merupakan naluri kemanusiaan. Ajaran Islam menganjurkan agar manusia berupaya menjadikan dunia bebas dari bahaya ketakutan. Niat ikhlas karena Allah untuk membantu sesama yang mengalami penderitaan merupakan landasan awal asuransi Islam. Premi yang dibayarkan kepada asuransi syariah harus didasarkan pada kerjasama dan tolong-menolong sesuai dengan perintah Allah untuk memperoleh ridha-Nya. Dari tujuan diatas beberapa $\mathrm{k}$ alangan berpendapat bahwa asuransi juga berorientasikan kepada pemberdayaan ekonomi masyarakat. Melalui aktivitas investasi yang dilakukan pihak perusahaan akan memberikan dampak kepada tumbuhnya perekonomian masyarakat. Dengan tujuan tersebut semakin meyakinkan bahwa manusia s e bagai mahluk s osial tidak dapat hidup tanp adanya interaksi sosial yang dilakukan. Sikap kebersamaan inilah yang dijunjung tinggi dengan berdirinya asuransi syariah. Harapan lebih jauh dari pendirian asuransi syariah ini adalah terciptanya kedamaian, ketentraman jiwa masyrakat. Dalam hal inilah asuransi syariah dituntut untuk memberikan kontribusinyata kepada masyarakat grass root ketimbang hanya mengambil pasar dari kalangan menengah keatas.

\section{PERBEDAAN TAKAFUL DENGAN ASURANSI KONVENSIONAL}

Darisekian banyak perbendaan asuransi konvensional dan asuransisyariah (takaful) berikut beberapa perbedaannya(Syakir, 2004 : 293-319).

\begin{tabular}{|c|c|c|c|}
\hline NO. & $\begin{array}{c}\text { HAL YANG } \\
\text { MEMBE- } \\
\text { DAKAN }\end{array}$ & $\begin{array}{c}\text { ASURANSI } \\
\text { KONVENSIONAL }\end{array}$ & $\begin{array}{c}\text { ASURANSI } \\
\text { SYARIAH }\end{array}$ \\
\hline
\end{tabular}


Studi Komparatif Takaful dan Asuransi Konvensional

\begin{tabular}{|c|c|c|c|}
\hline 1. & Konsep & $\begin{array}{l}\text { Perjanjian antara } \\
\text { dua pihak atau } \\
\text { lebih, dengan mana } \\
\text { pihak penanggung } \\
\text { mengikatkan diri } \\
\text { kepada tertanggung, } \\
\text { dengan menerima } \\
\text { premi asuransi, } \\
\text { untuk memberikan } \\
\text { penggantian } \\
\text { kepada tertanggung } \\
\text { atas klaim yang } \\
\text { diajukan. }\end{array}$ & $\begin{array}{l}\text { Sekumpulan } \\
\text { orang yang } \\
\text { saling } \\
\text { membantu, } \\
\text { saling } \\
\text { menjamin, } \\
\text { dan bekerja } \\
\text { sama, } \\
\text { dengan cara } \\
\text { masing- } \\
\text { masing } \\
\text { mengelu- } \\
\text { arkan dana } \\
\text { tabarru'. }\end{array}$ \\
\hline 2 & $\begin{array}{l}\text { Unsur Gharar, } \\
\text { Maisir, dan Riba }\end{array}$ & $\begin{array}{l}\text { Masih terdapat } \\
\text { adanya unsur } \\
\text { gharar, maisir, dan } \\
\text { riba. }\end{array}$ & $\begin{array}{l}\text { Harus } \\
\text { bersih dari } \\
\text { segala } \\
\text { praktik } \\
\text { gharar, } \\
\text { maisir, dan } \\
\text { riba. }\end{array}$ \\
\hline 3. & $\begin{array}{l}\text { Dewan } \\
\text { Pengawas } \\
\text { Syariah }\end{array}$ & $\begin{array}{l}\text { Tidak ada, hanya } \\
\text { diawasi oleh } \\
\text { Undang-Undang } \\
\text { dan Peraturan- } \\
\text { Peraturan } \\
\text { Pemerintah. }\end{array}$ & $\begin{array}{l}\text { Ada, yang } \\
\text { berfungsi } \\
\text { untuk } \\
\text { mengawasi } \\
\text { pelaksanaan } \\
\text { operasional } \\
\text { perusahaan } \\
\text { agar terbebas } \\
\text { dari praktik- } \\
\text { praktik } \\
\text { muamalah } \\
\text { yang } \\
\text { bertentangan } \\
\text { dengan } \\
\text { prinsip- } \\
\text { prinsip } \\
\text { syariah. } \\
\end{array}$ \\
\hline
\end{tabular}




\begin{tabular}{|c|c|c|c|}
\hline 4. & Akad & $\begin{array}{l}\text { Akad jual } \\
\text { beli (akad } \\
\text { mu'awadhah, } \\
\text { akad idz'aan, } \\
\text { akad gharar, } \\
\text { dan akad } \\
\text { mulzim) }\end{array}$ & $\begin{array}{l}\text { Akad tabarru' } \\
\text { dan akadtijarah } \\
\text { (mudharabah, } \\
\text { wakalah, } \\
\text { wadiah, syirkah, } \\
\text { dan sebagainya). }\end{array}$ \\
\hline 5. & $\begin{array}{l}\text { Penangan } \\
\text { Risiko }\end{array}$ & $\begin{array}{l}\text { Transfer of Risk, } \\
\text { di mana terjadi } \\
\text { perpindahan risiko } \\
\text { dari tertanggung } \\
\text { kepada penanggung. }\end{array}$ & $\begin{array}{l}\text { Sharing of Risk, } \\
\text { di mana terjadi } \\
\text { proses saling } \\
\text { menanggung } \\
\text { risiko antara satu } \\
\text { peserta dengan } \\
\text { peserta lainnya. }\end{array}$ \\
\hline 6. & $\begin{array}{l}\text { Pengelola } \\
\text { Dana }\end{array}$ & $\begin{array}{l}\text { Tidak ada pemisahan } \\
\text { dana, antara dana } \\
\text { peserta dengan dana } \\
\text { perusahaan yang } \\
\text { berakibat terjadinya } \\
\text { dana hangus. }\end{array}$ & $\begin{array}{l}\text { Terdapat } \\
\text { pemisahan } \\
\text { antara dana } \\
\text { tabarru' } \\
\text { dengan dana } \\
\text { perusahaan, } \\
\text { sehingga tidak } \\
\text { mengenal } \\
\text { istilah dana } \\
\text { hangus. }\end{array}$ \\
\hline 7. & Investasi & $\begin{array}{l}\text { Bebas melakukan } \\
\text { investasi dalam } \\
\text { batas-batas ketentuan } \\
\text { perundang-undangan, } \\
\text { dan tidak dibatasi } \\
\text { pada halal dan } \\
\text { haramnya objek atau } \\
\text { sistem investasi yang } \\
\text { digunakan. }\end{array}$ & $\begin{array}{l}\text { Dapat melakukan } \\
\text { investasi sesuai } \\
\text { ketentuan } \\
\text { perundang- } \\
\text { undangan, } \\
\text { sepanjang tidak } \\
\text { bertentangan } \\
\text { dengan prinsip- } \\
\text { prinsip syariah } \\
\text { Islam. bebas } \\
\text { dari } \\
\text { riba dan tempat- } \\
\text { tempat } \\
\text { investasi } \\
\text { yang } \\
\text { terlarang. }\end{array}$ \\
\hline
\end{tabular}




\begin{tabular}{|c|c|c|c|}
\hline 8. & $\begin{array}{l}\text { Kepemi- } \\
\text { likan Dana }\end{array}$ & $\begin{array}{l}\text { Dana yang terkumpul } \\
\text { dari premi tertanggung } \\
\text { seluruhnya menjadi } \\
\text { milik perusahaan. } \\
\text { Perusahaan bebas } \\
\text { menggunakan dan } \\
\text { menginvestasikan ke } \\
\text { mana saja. }\end{array}$ & $\begin{array}{l}\text { Dana yang } \\
\text { terkumpul dari } \\
\text { peserta dalam } \\
\text { bentuk iuran atau } \\
\text { kontribusi, tetap } \\
\text { merupakan } \\
\text { milik peserta, } \\
\text { entitas asuransi } \\
\text { syariah hanya } \\
\text { sebagai pemegang } \\
\text { amanah dalam } \\
\text { mengelola dana } \\
\text { tersebut. }\end{array}$ \\
\hline 9. & $\begin{array}{l}\text { Sumber } \\
\text { Pembayaran } \\
\text { Klaim }\end{array}$ & $\begin{array}{l}\text { Berasal dari } \\
\text { rekening } \\
\text { perusahaan, } \\
\text { sebagai } \\
\text { konsekuensi } \\
\text { penanggung } \\
\text { terhadap } \\
\text { tertanggung. }\end{array}$ & $\begin{array}{l}\text { Sumbernya } \\
\text { diperoleh } \\
\text { dari rekening } \\
\text { tabarru', } \\
\text { peserta saling } \\
\text { menanggung. } \\
\text { Jika salah } \\
\text { satu peserta } \\
\text { mendapat } \\
\text { musibah, } \\
\text { maka peserta } \\
\text { lainya ikut } \\
\text { menanggung } \\
\text { bersama risiko } \\
\text { tersebut. }\end{array}$ \\
\hline 10. & $\begin{array}{l}\text { Keuntungan } \\
\text { (Profit) }\end{array}$ & $\begin{array}{l}\text { Diperoleh dari surplus } \\
\text { underwriting, komisi } \\
\text { reasuransi, dan hasil } \\
\text { investasi seluruhnya } \\
\text { adalah keuntungan } \\
\text { perusahaan. }\end{array}$ & $\begin{array}{l}\text { Diperoleh } \\
\text { dari surplus } \\
\text { underwriting, } \\
\text { komisi } \\
\text { reasuransi, } \\
\text { dan hasil } \\
\text { investasi, bukan } \\
\text { seluruhnya } \\
\text { menjadi milik } \\
\text { perusahaan, } \\
\text { tetapi dilakukan } \\
\text { bagi hasil } \\
\text { dengan peserta. }\end{array}$ \\
\hline
\end{tabular}

\section{STUDI KASUS}

Pada bahasan sebelumnya dinyatakan bahwa peran asuransi dalam masyarakat adalah baik itu asuransi konvensional maupun asuransi syariah memiliki kelebihan dan kekurangannya masing-masing. Asuransi konvensional 
yang diklaim dengan unsur-unsur yang dilarang oleh syariah seperti riba, gharar, maisir. Dengan kelemahan tersebut bila dibandingkan dengan asuransi syariah asuransi konvensional lebih memiliki formula untuk menganyomi masyarakat grass root dalam memperoleh asuransi. Walaupun kelebihan ini masih terdapat kritik terhadap sistem yang dijalankan, seperti kurang pro-aktivnya perusahaan asuransi konvensional memberikan kemudahan kepada masyrakat grass root yang tidak terbiasa dengan kompleksitas birokrasi.

Asuransi syariah dengan prisip dan tujuan yang begitu baik tentu masih memiliki ruang bagi civitas akademika untuk ikut memberikan saran demi kemajuan asuransi syariah. Dalam hal penganyoman masyrakat grass root, asuransi syariah dipandang belum dapat sepenuhnya memberikan pelayanan kepada masyrakat grass root. Sehingga prinsip dan tujuan yang diagung-agungkan oleh pihak asuransi syariah masih hanya dinikmati kalangan masyarakat menengah keatas. Salah satu prinsip yang diusung oleh asuransi syariah adalah ruh tolong menolong sesama masyarakat. Tentu hal ini sangat didukung oleh aturan syari yang mengajarkan kepada umat Islam yang hendaknya saling bantu menbantu sesama muslim bila ditimpah suatu musibah. Begitu juga dengan tujuan mulia yang diusung oleh asuransi syariah, seperti memberikan rasa aman kepada sesama peserta asuransi. Hal ini juga sangat sesuai dengan apa yang telah diajaran syariah Islam dalam interaksi sosial masyarakat. Namun tujuan ini dirasa belum maksimal dirasakan bagi masyarakat grass root.

\section{Pertumbuhan Asuransi Di Indonesia}

Sampai dengan 31 Desember 2010, densitas asuransi secara keseluruhan tercatat sebesar Rp472.398,06 per kapita; mengalami kenaikan sebesar 27,78\% dibandingkan tahun 2009 sebesar Rp369.700 per kapita. Besar densitas ini menunjukkan tren kenaikan dibandingkan periode sebelumnya. Demikian juga data penetrasi asuransi juga mengalami k e naikan, $\mathrm{d}$ ari $1,62 \%$ pada 31 Desember 2009 menjadi $1,75 \%$ pada 31 Desember 2010. Densitas dan Penetrasi Asuransi 
Studi Komparatif Takaful dan Asuransi Konvensional

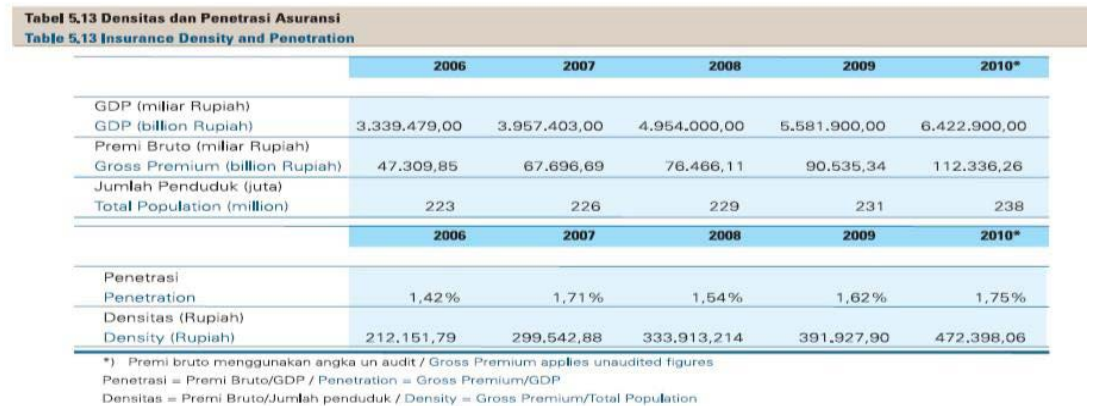

Sumber: Annual Report Bappepam-LK 2010

Struktur Pasar Perasuransian

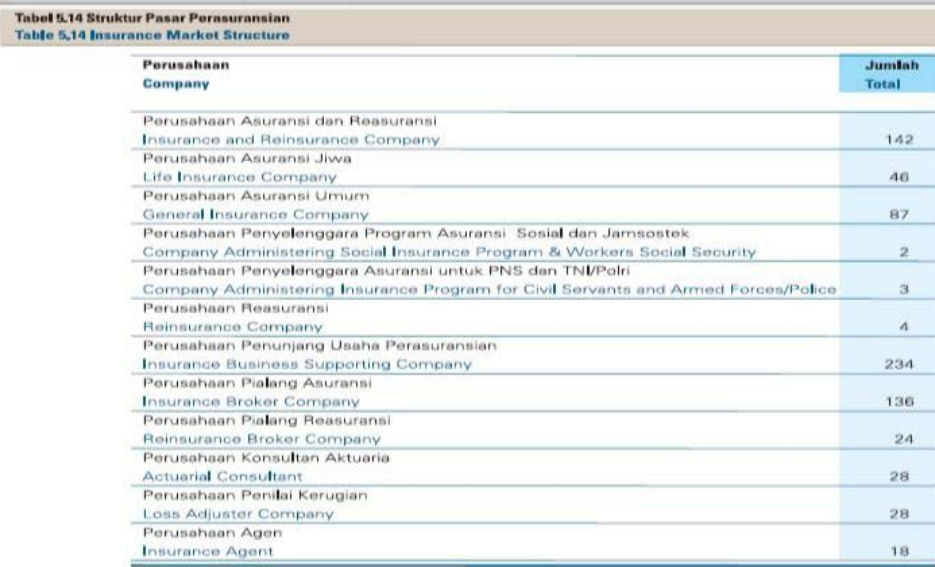

Sumber: Annual Report Bappepam-LK 2010

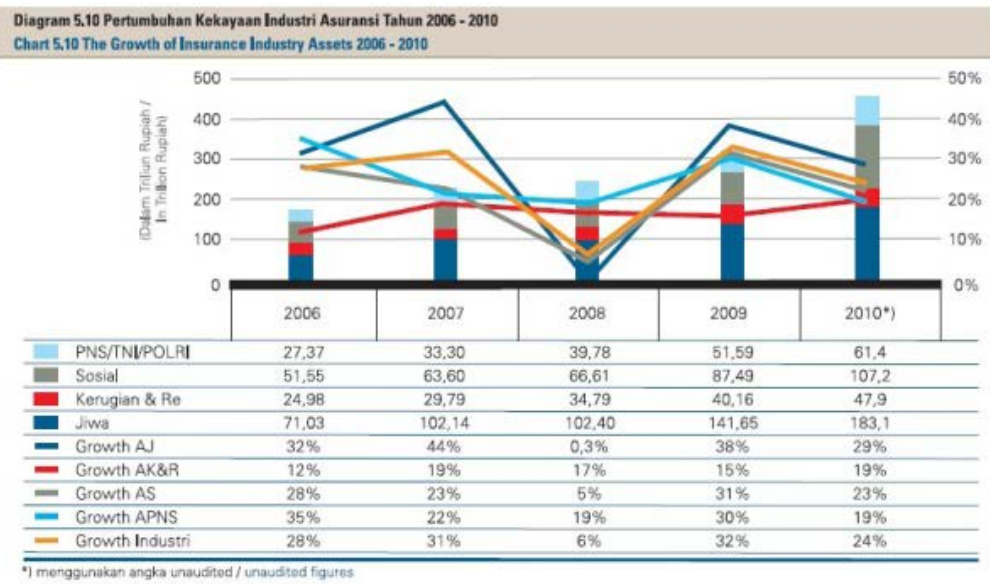

Pertumbuhan Kekayaan Asurani Tahun 2006-2010

BISNIS, Vol. 3, No. 2, Desember 2015 
Laba bersih setelah pajak asuransi jiwa per 31 Desember tahun 2010 adalah sebesar Rp6.347,3 miliar atau naik 33\% \%tase dibandingkan laba bersih tahun 2009. Sedangkan laba bersih setelah pajak asuransi kerugian dan reasuransi per 31 Desember tahun 2010 adalah sebesar Rp3.371,2 miliar atau naik 36\% dari laba bersih pada tahun 2009. Laba bersih setelah pajak seluruh asuransi komersial per 31 Desember tahun 2010 adalah Rp97.148,49 miliar atau naik 34\% d ari laba bersih y ang diperoleh pada tahun 2009 (Bappepam-LK, 2010).11

Rincian Laba Bersih Asuransi Komerial

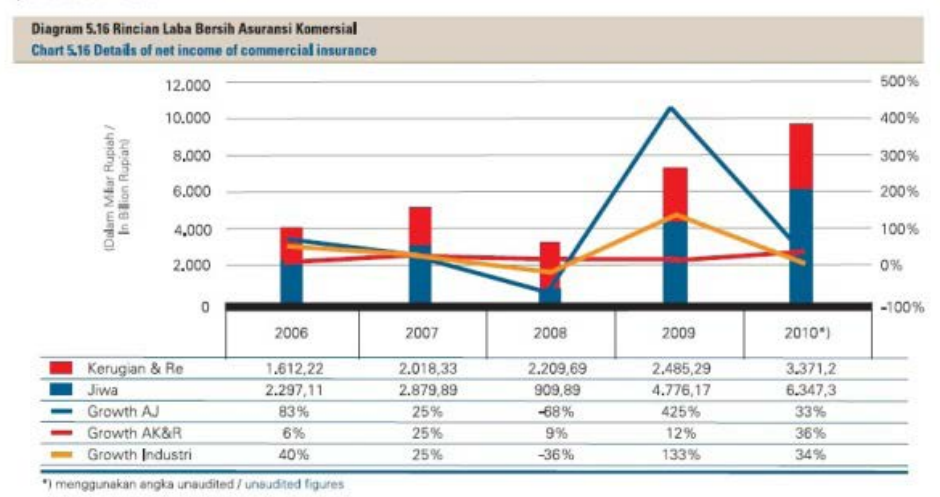

Sumber: Annual Report Bappepam-LK 2010.

Pada tahun 2011 asuransi konvensional dan asuransi syariah di Indonesia terus mengalami peningkatan yang positif, hal ini tercermin dari pertumbuhan perusahaan maupun pertumbuhan produk yang ditawarkan kepada masyarakat. Menurut laporan tahunan Bappepam-LK asset perusahaan asuransi meningkat hingga 18,84\% atau sebesar Rp481,50 Triliun. Dibanding dengan posisi pada akhir tahun 2010 atau nilainya meningkat dari Rp405,16 triliun menjadi Rp481,50 triliun. Sebesar 87,30\% atau Rp420,35 triliun dari total asset perusahaan asuransi dan perusahaan reasuransi tersebut ditempatkan dalam berbagai instrumen investasi. Total investasi ini mengalami kenaikan sebesar 17,93\% bila dibandingkan dengan tahun 2010 yang bernilai Rp356,45 triliun (Bappepam-LK, 2011 : 131). Sebaliknya keadaan asuransi Indonesia pada beberapa aspek cendrung mengalami penurunan. Mungutip publikasi Sigma World Insurance in 2010 yang dirilis oleh swiss Re pada tahun 
2011, Indonesia tergolong negara yang terpuruk dalam upaya perlindungan terhadap jiwa manusia, yang diukur dengan dua indikator yaitu insurance Density dan Insurance Penetration. Total premi - asuransi umum dan asuransi jiwa - negara dengan penduduk 240 juta jiwa ini pada tahun 2010 s e besar $\$ 10,7$ Milyar, atau meningkat 28,91\% dibandingkan dengan tahun 2009. Dengan nilai sebesar itu, Indonesia menempati peringkat ke-11 dari 27 negara di Asia. Peringkat pertama di tempati oleh Jepang, sedangan Singapura, Thailand, dan Malaysia ada di peringkat 7 sampai 9. Jika total premi tersebut dibagi dengan GDP - dikenal dengan insurance penetration - maka nilainya hanya 1,5\% dari GDP. Dengan insurance penetration sebesar itu, Indonesia menempati peringkat ke-16, namun jika ukurannya per-kapita, posisi Indonesia semakin melorot, yaitu pada posisi ke-22 di Asia, dengan nilai premi perkapita sebesar \$45.8. Itu adalah nilai premi perorang, yang jika dirupiahkan hanya sebesar - dengan kurs 8900 - sekitar Rp407.000 saja. Khusus untuk asuransi jiwa, total preminya sebesar \$7.2 Milyar, atau meningkat sebesar $31.1 \%$ di bandingkan tahun 2009. Posisi Indonesia berada pada pringkat ke-10 di Asia, dan Singapura, Thailand dan Malaysia persis berada di atas Indonesia. Jika dihitung perkapita - atau di kenal dengan Insurance Density nilai premi asuransi jiwa perkapita adalah sebesar 30.9 USD, atau hanya Rp 275.000.

Merosotnya peringkat Inurance Density Indonesia tidak terlepas dari beban jumlah penduduk yang justru masuk peringkat ke-4 di dunia.

Dari laporan tahunan Bappepam-LK Sigma World Insurance diatas menyatakan bahwa prospek asuransi di Indonesia masih terbuka lebar dalam pengembangan asuransi syariah. Namun mayarakat belum sepenuhnya sadar akan pentingnya asuransi yang dianggap dapat menjamin masa depan individu yang ikut dalam program asuransi. Pada laporan diatas terlihat bahwa peluang untuk asuransi syariah dalam memberdayaka Segala kemampuannya untuk mengayomi masyarakat grass root dengan mempromosikan tujuan dan prinsip yang sangat baik itu masih sangat terbuka lebar. Dengan demikian asuransi syariah diharapkan memberikan pengaruh yang lebih signifikan kepada masyarakat grass root. Ketiadaannya pengaruh kepada 
masyarakat akan cendrung menjadikan asuransi tidak memberikan nilai tambah (value added) kepada masyarakat grass root.

Melihat fenomena diatas asuransi syariah harus lebih giat dalam melakukan inovasi produk yang lebih memberikan kemudahan bagi masyarakat menengah kebawah. Kemudahan prosedur suatu produk asuransi syariah dapat memperbesar minat masyarakat dalam berasuransi. Asuransi syariah dapat melihat dari apa yang telah dilakukan oleh beberapa asuransi konvensional yang berhasil memberikan dampak langsung (direct effect) kepada masyarakat. Pada asuransi konvensional terdapat suatu produk yang mudah dan ringan bagi masyarakat grass root, seperti yang dilakukan Allianz serta ACA yang cukup inovatif dalam menggarap asuransi mikro (micro insurance). Allianz menawarkan dua skema asuransi yang pertama dan khusus disasarkan bagi perempuan di kalangan miskin Jakarta adalah TAMADERA yang menggabungan asuransi jiwa dan tabungan.

Nasabah membayar sekitar Rp10.000/minggu selama 5 tahun, dan mereka mendapat jaminan terhadap penyakit berat seperti kanker, stroke, serangan jantung, gagal ginjal, luka bakar dan lain-lain. Jika setelah 5 tahun tidak ada klaim, seluruh premi akan di kembalikan kepada nasabah. Utamanya Allianz mengungkapkan bahwa tabungan tersebut bisa digunakan untuk pendidikan anak. Produk kedua yang di keluarkan oleh Alllianz adalah Payung Keluarga, yang memberikan perlindungan mulai dari perlindungan dasar asuransi jiwa kredit bagi nasabah pinjaman kredit mikro dan pasangannya, sampai kepada manfaat tambahan yang dibayarkan kepada keluarga nasabah untuk membantu meringankan tantangan yang dihadapai keuangan keluarga setelah wafatnya sang pencari nafkah. Premi terendah mulai dari Rp6000. Dari contoh di atas bisakah asuransi syariah mengeluarkan produk yang di canangkan oleh asuransi konvensional diatas? Itulah tantangan dan peluang untuk mengembangkan asuransi syariah di Indonesia.

\section{KESIMPULAN}

Peluang untuk berkembangan asuransi syariah di Indonesia masih cukup besar. Hal ini dilihat dari berbagai 
laporan yang telah dirilis diatas. Asuransi syariah memiliki tujuan dan prinsip yang sangat berbeda dengan asuransi konvensional, oleh karena itu asuransi syariah diharapkan lebih dapat memberikan nilai tambah bagi masyarakat. Asuransi syariah juga diharapkan dapat menjangkau masyarakat grass root dengan melakukan inovasi produk yang ringan, mudah dan tepat pada sasaran. Dengan terjangkaunya asuransi syariah pada masyarakat menengah ke bawah prinsip dan tujuan asuransi syariah akan tercapai dengan baik, serta menghilangkan stigma bahwa asuransi hanya untuk kalangan menengah ke atas. 
Nur Hisamuddin

\section{DAFTAR PUSTAKA}

Bappepam-LK, Laporan Tahunan 2010, Kementrian Keuangan RI, Jakarta, 2010. Bappepam-LK, Laporan Tahunan 2011, Kementrian Keuangan RI, Jakarta, 2011.

Fatwa Dewan Syariah Nasional. No. 21/DSN-MUI/X/2001. Te ntang Pedoman Umum Asuransi Syariah.

Kaslan. A. Tohir. "Ekonomi Modern". Pradnya Paramita. Jakarta. 1975.

Kasmir. Bank dan Lembaga Keuangan Lainnya. Rajawali Pers. Jakarta. Ed Revisi. 2014.

Nurul Huda dan M. Haykal. Lembaga Keuangan Islam: Tinjauan Teoritis dan Praktis. h. 2010.

Muhammad Syakir Sula, Asuransi Syariah: Life and general: Konsep dan Sistem Operasional, Gema Insani Press, Jakarta, 2004, cet-1.

Undang-Undang Republik Indonesia Nomor 2 Tahun 1992 tentang usaha perasuransian.

Yadi jawari, Asuransi Syariah, Pustaka Bani Quraiy, Bandung, 2005. 